\title{
FDI Regulatory Reform and Political Beliefs: A Political Economy Approach
}

\author{
Louis Jaeck ${ }^{1,2 *}$, Sehjeong Kim³ \\ ${ }^{1}$ College of Business and Economics, Department of Economics and Finance, United Arab Emirates University, Al Ain, \\ United Arab Emirates \\ ${ }^{2}$ CERGAM-CAE, Aix-Marseille University (AMU), Marseille, France \\ ${ }^{3}$ Department of Mathematical Science, United Arab Emirates University, Al Ain, United Arab Emirates \\ Email: *louis_jaeck@uaeu.ac.ae, sehjung.kim@uaeu.ac.ae
}

How to cite this paper: Jaeck, L. and Kim, S. (2016) FDI Regulatory Reform and Political Beliefs: A Political Economy Approach. Theoretical Economics Letters, 6, 1205-1218. http://dx.doi.org/10.4236/tel.2016.66114

Received: September 23, 2016

Accepted: November 8, 2016

Published: November 11, 2016

Copyright $\odot 2016$ by authors and Scientific Research Publishing Inc. This work is licensed under the Creative Commons Attribution International License (CC BY 4.0).

http://creativecommons.org/licenses/by/4.0/

\begin{abstract}
This paper analyzes the setting of a reform towards liberalization of FDI policies as a political compromise pressured by the lobbying of a domestic lobby and a foreign MNC lobby. Using a common agency model of lobbying, we show that, under specific conditions, the interest group's influence is not distortive for a critical distribution of supporters over non-supporters of the reform. Also, our political economy framework shows that exogenous provision of information on the beneficial effects of FDI liberalization paradoxically weakens the reform process.
\end{abstract}

\section{Keywords}

Foreign Direct Investment, Lobbying, Common Agency, Beliefs, Political Economy

\section{Introduction}

In recent decades, multinational corporations (MNCs) have increased their foreign direct investment (FDI) activities worldwide and developing countries have been the main destination. FDI is the international flow of firm-specific asset such as production technologies, managerial and organizational practices, and trademarked brands. Usually, MNCs realize FDI through the establishment of new production facilities, or the merger and acquisition of an existing firm. The literature has traditionally distinguished two motives for FDI. Resource seeking FDI refers to firms willing to reduce production costs by relocating production to foreign countries abundant in necessary inputs, such as labor or natural resources. Market seeking FDI sees firms entering countries to produce goods and services for local sales. This strategy aims at reducing the burden of trade barriers and transportation costs. During the period between 1990 
and 2013, the amount of FDI inflows had jumped from 35,000 to 77,000 million dollars and their share directed to the developing nations was $52 \%$ of global FDI inflows in 2013 (UNCTAD [1]). To explain such massive evolution in international economic flows, a vast literature has focused on how governments compete to attract FDI. Indeed, the democratization process occurring in the 1990s, with a large number of countries adopting free market economic policies, paved way for interstates competition to attract foreign investment. Indeed, FDI would yield infrastructure upgrading, promote technology transfer and improve managerial knowledge; those factors are of most importance to compete in global markets (Dunning [2]). FDI are also credited with boosting economic growth (Alfaro et al. [3]) and reducing unemployment (Spiezia [4]; Vacaflores [5]). Such interstate competition has been witnessed mainly in developing countries as developed countries already exhibit high quality infrastructure, property rights protection and an educated work force, thus reducing the need for them to compete. Unsurprisingly, relaxing FDI regulation such as those on ownership, the creation of special economic zones, and lowering taxation on corporations have been widespread policies to attract FDI ${ }^{1}$. For instance, Kobrin [6] showed that during the period between 1992 and 2001, 95\% of the 1086 individual policy changes either lessened restrictions on inflows of FDI or provided incentives to attract them.

However, interest groups' influence has been credited to be of great importance in shaping FDI policy changes. Using an original dataset of FDI regulation covering the period between 1962-2000 over 150 countries, 57 industries and 12 specific regulations that represent the most common barriers to $\mathrm{FDI}^{2}$, Pandya [7] found that industries in which firms invest to gain market access such as service industries are more likely to be restricted, as powerful domestic producers lobby for protection. FDI policies and regulations may thus serve as a way to protect the national economy. So far, this theoretical debate has been investigated by political economists who focused on the interaction between FDI and trade policy. It started with the seminal argument that foreign firms try to circumvent protectionist barriers that impediment exports sales via setting up local production (Corden [8]). Other formulation refers to the quid pro quo FDI, where the motive for foreign investment is the pre-emption barriers that might otherwise be implemented (Baghwati [9]) $)^{3}$. Dinopoulos and Wong [10] have shown that increased FDI by foreign entities will reduce protection threats against foreign imports in the host country. Quid pro quo investment is thus described as "indirect rent-seeking" via con-

\footnotetext{
${ }^{1}$ The literature has focused on spatial econometrics to explore the extent of competition in tax, environmental standards, economic policy reforms, bilateral investment treaties and labor standards. The reader may refer to Cooray et al. [13] for an excellent survey of this literature.

${ }^{2}$ The United Nations identifies sixty distinct policy measures that countries use to restrict FDI (UNCTAD [14]). Pandya restricts his analysis to the following: bans on foreign ownership, majority local ownership requirements, government monopoly, mandatory joint ventures, compulsory investment pre-screening, local content requirements, minimum exports quotas, discriminatory tax policy, caps on capital and profit repatriation, limits on access to foreign exchange, local employment minimums and mandatory local representation on boards of directors. Note that the first five policy instruments listed above restrict FDI by limiting foreign investors' market access. The remaining seven are regulations that apply to foreign and not to nationally-owned firms.

${ }^{3}$ See Baghwati et al. [15] for a survey.
} 
sensual policies (Hillman and Ursprung [11]). The quid pro quo investor seeks a liberal trade policy, and will eventually be deterred if trade liberalization does not occur. For instance, Zhao [12] has demonstrated how such investment is pre-empted if labor unions lobby a host country's government for protectionist policies. Similarly, Hillman and Ursprung [11] argue that such foreign investment could not take place if the foreign investor acquires a domestic monopoly firm. Confronting to import competition, the foreign investor supplying the domestic market may thus lobby for protection. The focus of this literature is whether the presence or threat of protection gives rise to FDI. On the other hand, other papers have studied how the presence of multinational firms affects the emergence of protection. In Hillman and Ursprung [16]'s model, domestic and multinational firms exposed to foreign competition lobby for protection in the jurisdictions where they have plants ${ }^{4}$. Contrary to Hillman and Ursprung [16], Ellingsen and Warneryd [17] developed a model where the domestic industry lobby for less protection, as a high level of protection could attract more FDI aimed at avoiding trade barriers and thereby harming domestic firms.

Overall, this literature has focused on the political economy of the supply of FDI inflows which represents one dimension of FDI's politics. The political economy of FDI demand has been under-investigated, however. Scheve and Slaughter [18] have argued that FDI can increase the elasticity of labor demand in host countries, thus feeding job insecurity. Their finding suggests that individuals who perceive their jobs to be less secure may be less supportive of FDI. Preferences over international economic flows are complex and multidimensional. As such, they are not exclusively a function of the direct effects of economic flows, rather, they may the result of systematically biased political beliefs. For instance, relying on the Survey of Americans and Economists on the Economy from Harvard University, Caplan [19] argues that citizens would have an “anti-foreign" bias leading them to underestimate the benefits from free trade. Nevertheless, education would play a beneficial role in fostering the support for international economic flows. According to Hiscox and Hainmueller [20], higher education encourages individuals to have more cosmopolitan preferences and provides the requisite economic literacy to appreciate the welfare gains to free trade. Similarly, relying on the annual public opinion survey conducted in 18 Latin American countries, Pandya [21] has empirically shown that more educated individuals are persuaded by the economic benefits of FDI, thus emphasising the importance of ideas in the formation of preferences for international economic flows ${ }^{5}$.

\footnotetext{
${ }^{4}$ They show, however, that the presence of multinational firms in an industry may encourage trade liberalization under specific conditions.

${ }^{5}$ Surveys from 1995, 1998, and 2001 included the question: "Do you consider that foreign investment, in general, is beneficial or is it harmful for the economic development of the country?" The 1998 and 2001 surveys ask a different but related question: "Do you strongly agree, agree, disagree, or strongly disagree with the phrase: foreign investment should be encouraged?" The author also provides a comprehensive test of FDI's predicted effects on individual income. In support of Pandya [21]'s argument, Leeson et al. [27] have highlighted that ideas matter in shaping citizens' attitudes towards free market policies in the U.S. Relying on questions from the General Social Surveys that ask respondents their opinions about the government's relationship to the economy, they found that where think tank spending is higher, citizens have more "pro-market" attitudes toward economic policy.
} 
In this paper, we seek to unify these two dimensions of FDI politics within the framework of the common agency model of lobbying (Grossman and Helpman [22]). Contrary to conventional political economy models that assume citizens are rationally ignorant of the functioning of the economy and the impact of economic policies (Converse [23]; Page and Shapiro [24]; Deli et al. [25]), we assume that the population exhibit heterogeneous political beliefs concerning international economic flows and in particular on the effects of FDI liberalization policies. In doing so, we fill a methodological gap highlighted by Rodrik [26] who insists on the necessity to account for ideas and beliefs in political economic modelling. The main contribution of the paper is to show that information provision related to the beneficial effects of FDI liberalization policies may paradoxically lead to less liberalization. This counter-intuitive result lies with the structure of the political economy setting and interdependence effects between lobbies' activities and the evolution of citizens' beliefs.

The paper is organized as follows: Section 2 presents the framework of our model in which we consider that society is not homogeneous with respect to citizens' beliefs over the effects of FDI liberalization policies. In Section 3, we develop the common agency model of lobbying. We analyze the setting of the reform in FDI policies as a political compromise pressured by interest groups. The latter are composed of a domestic industry lobby and a foreign MNC lobby that have opposed interests. They both lobby the government by offering political campaign contributions. In Section 4, we investigate the policy distortion resulting from interest groups' influence by comparing the equilibrium level of policy change with its socially optimal value. We show that interest groups' influence may not be socially distortive under certain conditions. Section 5 explores the exogenous effect of information provision on the equilibrium level of FDI policy change. The last section presents some concluding remarks.

\section{The Model}

In this section we develop the assumptions of our basic economic model. We describe the utility functions and their arguments. In the spirit of Tagkalakis [28] and Jaeck and Kim [29], we formulate the unemployment equation as follows:

$$
u=a(\ln w-\ln \pi)-\delta v
$$

where $u$ is the unemployment rate; $w$ is the nominal wage; and $\pi$ is the inflation rate. Note that $w-\pi$ represents the real wage. We assume that there is a level of FDI policies, $\bar{\varepsilon}$, that corresponds to the current level of FDI rules and regulations which is normalized to 1 so that its $\log$ is zero. Therefore, $v=v(\varepsilon)=\ln \varepsilon$ is a composite index that represents the strength of liberalization of FDI policies with $\varepsilon \in[1 ;+\infty[$ and $\partial v / \partial \varepsilon>0$. Such indices consider FDI policies that affect foreign investors' market access $^{6}$. The liberalization process is specified as a continuous variable; when $v$ increases, the liberalization process becomes stronger. The parameter a measures the impact of

${ }^{6}$ As an example, and building on Pandya [7], we assume that FDI regulations subjected to the softening process are related to bans on foreign ownership, majority local ownership requirements, mandatory joint ventures, or compulsory investment pre-screening. 
the real wage, $(a>0)$ and $\delta$ measures the impact of FDI liberalization policies $(\delta>0)$. This latter assumption is supported by empirical evidence showing the positive impact of FDI in reducing the unemployment rate in Latin America (Vacaflores [5]), Central Europe (Radosevic et al. [30]), the Czech Republic (Dinga and Munich [31]) and in Italy (Spieza [4]). Therefore, the unemployment rate increases with the real wage $(w-\pi)$ and decreases with the index $v$ (i.e. deviation from the current state of rules and regulation of FDI; so if $v=0$, no FDI liberalization policy is undertaken).

The population is composed of $N$ citizens. Following Caplan [19]'s empirical contribution we assume that there are two types of citizens: those who believe in the beneficial effects of liberalization of FDI policies on reducing unemployment (informed citizens) denoted by $N^{i}$, and those who do not (misinformed citizens) denoted by $N^{m 7}$. Alternatively, informed and misinformed citizens are assumed to hold correct and biased beliefs, respectively. Thus, the society is not homogenous with respect to citizens' beliefs over liberalization policies ${ }^{8}$.

$N$ represents the total population with $N=N^{i}+N^{m}$. To capture the impact of citizens' preferences for international economic flows on the political equilibrium, we assume that citizens' utility is essentially driven by the impact of FDI liberalization policies on the unemployment rate $^{9}$. The representative utility function of an informed citizen is given by:

$$
U^{i}=1-\left\{a(\ln w-\ln \pi)-\delta^{i} v\right\}
$$

This representative informed citizen believes in the positive effects of liberalization on the level of unemployment. When the deregulation process increases, the unemployment rate decreases, and thus the utility increases. This is represented by $\partial U^{i} / \partial v>0$. The term $\delta^{i} v$ may be interpreted as the citizen's belief over the effect of the liberalization process. We assume $\delta^{i}=\delta$, indicating that informed citizens have correct beliefs, $\delta^{i} v=\delta v$.

The representative utility function of a misinformed citizen is represented by:

$$
U^{m}=1-\left\{a(\ln w-\ln \pi)-\left(1 / \delta^{m} v\right)\right\}
$$

The representative misinformed citizen does not believe in the beneficial effect of FDI liberalization policies leading to a misconception of the unemployment rate $u=a(\ln w-\ln \pi)-\left(1 / \delta^{m} v\right)$, with $\delta^{m}=\delta^{m}(\mu)^{10}$. When FDI liberalization process increases, the unemployment rate increases, and thus the utility decreases. This is ${ }^{7}$ Based on the Survey of Americans and Economists on the Economy from Harvard University, Caplan [19] found that citizens would have an "anti-foreign" bias leading them to underestimate the benefits from free trade. We assume that such biased perception may also hold for the benefits of FDI liberalization policies.

${ }^{8}$ This assumption contrasts with the seminal standard assumption of citizens' rational ignorance that prevails in the public choice literature. The question of the origin of biased beliefs is left out of the paper. Biased beliefs may result from exposure to activist groups (Saint-Paul [32]; Jaeck [33]) or ideology (MacDonald and Rabinowitz [34]).

${ }^{9}$ The assumption is in line with the seminal results of MacCulloch et al. [35] who showed that individual happiness increases when the unemployment rate decreases.

${ }^{10}$ This assumption is motivated by Caplan [19]'s empirical evidenced demonstrated an "anti-foreign bias" as well as Scheve and Slaughter [18] showing that individuals are less supportive of FDI if they perceive their jobs to be insecure. 
represented by $\partial U^{m} / \partial v<0$. However, it is assumed that external information related to the beneficial effects of liberalization policies, $\mu$, compensates this bias. With $\mu \in\left[1 ;+\infty\left[, \quad \delta^{m}(1)=\delta^{m}>0\right.\right.$ and $\partial \delta^{m} / \partial \mu<0$. Thus, $\partial U^{m} / \partial \mu>0$, everything else being equal ${ }^{11}$.

\section{The Political Process}

In this section we develop the political model which is based on the common agency framework (Grossman and Helpman [22]). We characterize how interest groups' influence affect the political equilibrium. We consider two competing firms that operate in the service industry and produce the same good. The formation of the FDI policies easing market access in the home country is subject to the influence of interest groups. For methodological purpose, we first assumed that no external information on the beneficial effects of FDI liberalization policies is undertaken, therefore $\delta^{m}=\delta^{m}(1)$ is given. A domestic and a foreign MNC that belong to the home and foreign country, respectively, from distinct lobbies $j$, with $j=d$; f representing the domestic and foreign lobby respectively. Each lobby offers political contributions to the government. This money is for 'direct political influence' as it supports the electoral campaign for the reelection of an incumbent government ${ }^{12}$. As a reward, lobbies expect to obtain a better access to the legislator (Grossman and Helpman [22]). In our case, both lobbies are concerned with the degree of liberalization of FDI policies, $v(\varepsilon)$, but with opposed interests, and therefore, compete for influence. The domestic lobby supports a low level of liberalization as it seeks protection from competing foreign investors ${ }^{13}$. On the other hand, the MNC lobby supports more liberalization as it seeks market access. Following Olson [36], we also assume that citizens (informed and misinformed) are too numerous to overcome the free-rider problem and as such they do not organize themselves into a lobby group. To examine how political contributions provided by lobbies affect the equilibrium level of FDI policies, we use a common agency model of lobbying (Grossman and Helpman [22]) which is a two-stage game. The timing of the game can be expressed as following: In the first stage, each lobby presents to the government a contribution schedule, $s(v)$, which is contingent upon the level of FDI policies chosen by the government. In the next stage, the government sets the liberalization policy and collects the political contributions. Analyzing the determination of the political equilibrium requires first to define the aggregate welfare of each lobby $j$.

The domestic lobby's gross welfare function is represented by the domestic firm

\footnotetext{
${ }^{11}$ This assumption is motivated by Pandya's [21] study that relies on the annual public opinion survey conducted in 18 Latin American countries. Results clearly indicate that attitudes in favor of FDI increase with the level of education.

${ }^{12}$ IDEA [37] lists 41 countries with bans or other forms of restrictions on foreign donations to political parties. This includes the United Kingdom, France, Brazil, Canada, and Argentina. However, there are some examples of countries which do not impose bans such as Australia, Colombia, Denmark and Germany (Aidt and Hwang [38]). Gawande et al. [39]) have shown that foreign lobbies significantly impact the setting of tariffs and non-tariff trade barriers in the U.S. and that foreign activity may be welfare-enhancing.

${ }^{13}$ This assumption is in line with Pandya [7]'s results showing that industries in which firms invest to gain market access such as service industries are more likely to be restricted, as powerful domestic producers lobby for protection.
} 
profit:

$$
\pi^{d}=R^{d}(v)-c^{d}
$$

where $R^{d}(v)$ is the total revenue with $\partial R^{d} / \partial v<0$, and $c^{d}>0$ the total cost function.

The MNC lobby's gross welfare function is represented by the MNC profit:

$$
\pi^{f}=R^{f}(v)-c^{f}
$$

where $R^{f}(v)$ is the total revenue with $\partial R^{f} / \partial v>0$, and $c^{f}>0$. We further assume that $c^{f}<c^{d}{ }^{14}$. The relationship between $\partial R^{d} / \partial v<0$ and $\partial R^{f} / \partial v>0$ shows that an increase in the FDI liberalization process raises the profit of the MNC as it could expand its production, and reduces the one of the domestic firm as it loses market shares ${ }^{15}$. Each lobby sets up its contribution schedule so as to maximize its net welfare, which is the difference between the gross welfare and its contributions. Then, the government chooses the policy that maximizes a weighed sum of the aggregate social welfare and the received contributions. Following Grossman and Helpman [22] we assume that contribution schedules are globally truthful as they reflect everywhere the lobby's true welfare (Bernheim and Winston [40]). With this global truthfulness assumption, the political equilibrium is the solution of a program in which the government seeks to maximize an objective function, which is the sum of the aggregate social welfare $W$ and the interest of the active lobbies. It is such that ${ }^{16}$ :

$$
\operatorname{Max}_{v} G=\varphi^{d} \pi^{d}+\varphi^{f} \pi^{f}+W
$$

The parameter $\varphi^{j} \in[0,1], j=d, f$ represents the interest group's ability to influence the policymaker. It depends on exogenously determined factors such as political skills. A higher value of $\varphi^{j}$ means that the lobby $j$ can better influence the government that puts a higher weight on the contribution offered by lobby $j$. We assume that interest groups can have different lobbying efficiencies and $\varphi^{d}$ can be either greater or lower than $\varphi^{f}$. The social welfare function, $W$, exhibits three components: the informed citizen's welfare, the misinformed citizen's welfare, and the contribution received by the government respectively:

$$
W=W^{i}+W^{m}+s^{d}+s^{f}
$$

where $W^{i}$ is the informed citizen's aggregate welfare equal to:

$$
W^{i}=N^{i} U^{i}=N^{i}\{1-[a(\ln w-\ln \pi)-\delta v]\}
$$

And $W^{m}$ is the misinformed citizen's aggregate welfare equal to:

\footnotetext{
${ }^{14}$ Aitken, Harrison, and Lipsey [41] evidenced declining productivity for local firms competing with MNC as they face increased production costs due to greater labor demand.

${ }^{15}$ These assumptions are in line with FDI's negative effects for local firms such as loss of market share due to increased foreign competition (Chari and Gupta [42]).

${ }^{16}$ The objective function of the government without considering the global-truthfulness assumption would be as follow, $G=\varphi^{d} s^{d}+\varphi^{f} s^{f}+W$. If one considers the global-truthfulness property, the original objective function is re-written as Equation (6).
} 


$$
W^{m}=N^{m} U^{m}=N^{m}\left\{1-\left[a(\ln w-\ln \pi)-\left(1 / \delta^{m} v\right)\right]\right\}
$$

Differentiating Equation (6) with respect to $V$, we obtain the first-order condition of government optimization:

$$
G_{v}=\varphi^{d} \pi_{v}^{d}+\varphi^{f} \pi_{v}^{f}+W_{v}=0
$$

Here, $G_{v}$ measures the government's marginal benefits from promoting FDI liberalization policies. The second-order condition requires that this variation is decreasing in $v$ such that $G_{v v}<0$. The relation in (10) contains a key characteristic of the model. Around the truthful equilibrium, a policy change induces a variation in each lobby's contribution that is exactly equal to the variation in this lobby's gross welfare.

In particular, a marginal increase in $v$ induces variations in the domestic lobby and MNC's contributions by the amount of $\pi_{v}^{d}$ and $\pi_{v}^{f}$, respectively. In what follows, we define respectively $\pi_{v}^{d}$ and $\pi_{v}^{f}$ as the domestic lobby and the MNC lobby's marginal willingness to contribute (MWTC) for a marginal change in the FDI liberalization process, $v$. In equilibrium, $\partial \pi^{d} / \partial v=\pi_{v}^{d}=\partial R^{d} / \partial v$ is negative, meaning that the domestic lobby is willing to offer less political contributions in exchange for a strengthening of the FDI liberalization process, as such policies reduce its total revenue. Also, $\partial \pi^{f} / \partial v=\pi_{v}^{f}=\partial R^{f} / \partial v$ is positive. This means that the MNC lobby is willing to increase its contribution when the FDI liberalization process strengthens as it could enhance the MNC to expand its production. Equation (10) shows that the political equilibrium level of FDI policy change is chosen as a compromise between political contributions from interest groups and social welfare.

\section{Political Equilibrium Policy}

In this section, our primary focus is to compare the two equilibria $\left(v^{o}\right)$ and $\left(v^{*}\right) \cdot v^{*}$ is the socially optimal level of FDI policy change, which corresponds to an equilibrium when there are no direct lobbying. $v^{o}$ is the equilibrium level of FDI policy change that results from the direct influence of lobbies. Analyzing the deviation between $v^{o}$ and $v^{*}$ will provide us with a better understanding of the distortion resulting from direct political influence. Using Equation (7) and rearranging, we first set out the socially optimal level of FDI policy change, which is the solution of the following first-order condition ${ }^{17}$ :

$$
W_{v}\left(v^{*}\right)=W_{v}^{i}\left(v^{*}\right)+W_{v}^{n m}\left(v^{*}\right)+\pi_{v}^{d}\left(v^{*}\right)+\pi_{v}^{f}\left(v^{*}\right)=0
$$

with $W_{v}^{i}\left(v^{*}\right)=N^{i}[\delta(1 / \varepsilon)]>0$ and $W_{v}^{m}\left(v^{*}\right)=-\left\{(1 / \varepsilon) N^{m} /(v)^{2} \delta^{m}\right\}<0$.

The second order condition requires that $W_{v v}<0$. Equation (11) shows that relaxing FDI regulations increases the informed citizen's welfare, decreases the misinformed citizen's welfare and increases (decreases) the MNC lobby's welfare and (the domestic lobby's welfare), respectively. The optimal level of FDI policy reform should balance the four factors. From (11) we get:

\footnotetext{
${ }^{17}$ When deriving the following condition, we use the relationship $S_{v}^{d}=\pi_{v}^{d}$ and $s_{v}^{f}=\pi_{v}^{f}$. This relationship
} occurs as a result of the global-truthfulness property of the contribution schedules. 


$$
\pi_{v}^{d}\left(v^{*}\right)=-W_{v}^{i}\left(v^{*}\right)-W_{v}^{m}\left(v^{*}\right)-\pi_{v}^{f}\left(v^{*}\right)
$$

To compare $v^{o}$ and $v^{*}$, we evaluate Equation (10) at $v^{*}$ and given the first order condition $W_{v}\left(v^{*}\right)=0$ we obtain:

$$
G_{v}\left(v^{*}\right)=\varphi^{d} \pi_{v}^{d}\left(v^{*}\right)+\varphi^{f} \pi_{v}^{f}\left(v^{*}\right)
$$

In (13), with the second order condition $G_{v v}<0$, if $G_{v}\left(v^{*}\right)$ is positive (negative), the equilibrium level of FDI policy change is higher (lower) than the social optimum. It is equal, and $v^{0}=v^{*}$ when $G_{v}\left(v^{*}\right)=0$. If $\varphi^{d}=0, \varphi^{f}>0$, then $G_{v}\left(v^{*}\right)=\varphi^{f} \pi_{v}^{f}\left(v^{*}\right)>0$. When the MNC is the only one lobbying actively, the equilibrium level is higher than the optimal level. Similarly, if $\varphi^{d}>0, \varphi^{f}=0$, then $G_{v}\left(v^{*}\right)=\varphi^{d} \pi_{v}^{d}\left(v^{*}\right)<0$. When the domestic lobby is the only one lobbying actively, the equilibrium level is lower than the optimal level. These results are expected. We consider the particular case where the two lobbies have the same political efficiency, such that $\varphi^{d}=\varphi^{f}$. Combining (12) and (13), we get:

$$
G_{v}(v)=\left(\varphi^{f}-\varphi^{d}\right) \pi_{v}^{f}\left(v^{*}\right)+\varphi^{d}\left\{-N^{i}[\delta(1 / \varepsilon)]+\left[(1 / \varepsilon) N^{m} /(v)^{2} \delta^{m}\right]\right\}
$$

From Equation (14), the following proposition shows the relationship between $v^{o}$ and $v^{*}$ when $\varphi^{f}=\varphi^{d}$ :

Proposition 1: If the two lobbies have the same political efficiency $\left(\varphi^{d}=\varphi^{f}\right)$, the equilibrium level of FDI policy change is equal to the optimal level if the ratio of informed over misinformed citizens equals a critical value $A$. These results hold everything else being equal.

From Equation (14), when $\varphi^{d}=\varphi^{f}$, the sign of $G_{v}\left(v^{*}\right)$ depends on the sign of $\left\{-N^{i}[\delta(1 / \varepsilon)]+\left[(1 / \varepsilon) N^{m} /(v)^{2} \delta^{m}\right]\right\}$. Therefore, we have $G_{v}\left(v^{*}\right)=0$ for $\left(N^{i} / N^{m}\right)=1 / \delta^{m} \delta(v)^{2}=A>0$, and thus $v^{o}$ equals $v^{*}$. The intuition behind proposition 1 is that in the case where $\varphi^{d}=\varphi^{f}$, when the level of policy change is optimally set, the marginal welfare effects of changing $v\left(W_{v}\right)$ is equal to zero, so the value of $G_{v}$ depends on the two lobbies' MWTCs. From Equation (13), $G_{v}\left(v^{*}\right)=0$ implies that $\pi_{v}^{f}\left(v^{*}\right)=\left|\pi_{v}^{d}\left(v^{*}\right)\right|$, the domestic lobby's MWTC for a marginal change in FDI liberalization policies equals the $\mathrm{MNC}$ one, resulting in the equilibrium level equals to its socially optimal level.

Corollary: The equilibrium level is higher than its socially optimal value if this ratio falls below the critical value $A$. It is lower than the optimal level if the ratio increases above $A$. These results hold everything else being equal.

When $\left(N^{i} / N^{m}\right)<A, G_{v}\left(v^{*}\right)>0$ and thus $v^{O}>v^{*}$. Similarly, under $v^{*}$ the government has to balance the impacts of strengthening the level of liberalization on informed citizens' welfare $\left(W_{v}^{i}\right)$, on misinformed citizens' welfare $\left(W_{v}^{m}\right)$ and on the contributions from the domestic lobby $\left(\pi_{v}^{d}\right)$ and the MNC lobby $\left(\pi_{v}^{f}\right)$. Since $W_{v}^{i}\left(v^{*}\right)>0$, $W_{v}^{m}\left(v^{*}\right)<0, \pi_{v}^{d}\left(v^{*}\right)<0$ and $\pi_{v}^{f}\left(v^{*}\right)>0$, the condition

$W_{v}\left(v^{*}\right)=W_{v}^{i}\left(v^{*}\right)+W_{v}^{m}\left(v^{*}\right)+\pi_{v}^{d}\left(v^{*}\right)+\pi_{v}^{f}\left(v^{*}\right)=0$ implies that when $\left|W_{v}^{m}\left(v^{*}\right)\right|$ in- 
creases under the influence of the growing number of misinformed citizens, either $\pi_{v}^{f}\left(v^{*}\right)$ must increase or $\left|\pi_{v}^{d}\left(v^{*}\right)\right|$ must decrease. The intuition is that because misinformed citizens and the domestic lobby have common interests as they both support the status quo towards strong FDI regulations, interdependence effects occur between these two groups. Given that strengthening the liberalization process would decrease the welfare of misinformed citizens, the government has an incentive to weaken the liberalization process. This would incentivize the domestic lobby to reduce its contribution for a marginal tightening of FDI regulation as it indirectly benefits from the change in the welfare of the misinformed. Comparatively, the domestic lobby contributes less than the MNC lobby for a marginal change in the FDI liberalization policies, resulting in a higher equilibrium level of liberalization. Similarly, when $\left(N^{i} / N^{m}\right)>A, G_{v}\left(v^{*}\right)<0$ and thus $v^{O}<v^{*}$. The condition $W_{v}\left(v^{*}\right)=W_{v}^{i}\left(v^{*}\right)+W_{v}^{m}\left(v^{*}\right)+\pi_{v}^{d}\left(v^{*}\right)+\pi_{v}^{f}\left(v^{*}\right)=0$ implies that when $\left|W_{v}^{i}\left(v^{*}\right)\right|$ increases under the influence of the growing number of informed citizens, either $\pi_{v}^{f}\left(v^{*}\right)$ must decrease or $\left|\pi_{v}^{d}\left(v^{*}\right)\right|$ must increase. Given that strengthening the liberalization process would increase the welfare of informed citizens who become a large number in the society, the government has an incentive to do so. Because informed citizens and the MNC lobby have common interests as they both support more FDI liberalization, interdependence effects might also occur between these two groups. This would incentivize the MNC lobby to decrease its contribution for a marginal softening of FDI regulation as it indirectly benefits from the change in the welfare of the informed. Comparatively, the domestic lobby contributes more than the MNC lobby for a marginal change in the FDI liberalization policies, resulting in a lower equilibrium level of liberalization.

\section{The Effect of Information Provision}

In this section, we investigate the effect of an exogenous provision of information regarding the beneficial effects of FDI liberalization, $\mu$, on the equilibrium level of FDI liberalization policy. We assume that such external information may come from different sources of the civil society such as think tanks for instance. Since $\mathrm{d} v^{O} / \mathrm{d} \mu=-G_{v \mu} / G_{v v}$, the sign of $\mathrm{d} v^{O} / \mathrm{d} \mu$ depends on the sign of $G_{v \mu}$ since $G_{v v}<0$. By differentiating $G_{v}$ with respect to, we obtain:

$$
G_{v \mu}=\left\{\left(\partial \delta^{m} / \partial \mu\right)\left(N^{m} / \varepsilon\right)\right\} /\left(\delta^{m}\right)^{2}(v)^{2}<0
$$

With $G_{v \mu}<0$, we reach the following proposition on the effect of information provision on the level of FDI policy change. This proposition holds for any $\varphi^{j} \in[0,1]$.

Proposition 2: Information provision on the beneficial effects of FDI leads to weaken the FDI liberalization process.

The political effects of information provision on the stringency of FDI policies depend on the impact of information provision on $G_{v}$, the marginal benefit to the government arising from tightening the liberalization process. Here, the negative sign of $G_{v \mu}$ shows that the effect of information provision leads paradoxically to less liberali- 
zation of FDI policies. This is because the marginal benefits to the government increase when the liberalization process is weakened. The intuition lies with interdependence effects between lobby groups and citizen's welfare. Indeed, the increase in information provision compensates for the loss of misinformed citizens' welfare resulting from more liberalization, $\partial\left|W_{v}^{m}\left(v^{*}\right)\right| / \partial \mu=\left\{\left(\partial \delta^{m} / \partial \mu\right)\left(N^{m} / \varepsilon\right)\right\} /\left(\delta^{m}\right)^{2}(v)^{2}<0$. By analogy with proposition 1, this would incentivize the MNC lobby to decrease its contribution for a marginal softening of FDI regulation as it indirectly benefits from the change in the welfare of misinformed citizens. Comparatively, the domestic lobby contributes more than the MNC lobby for a marginal change in the FDI liberalization policies, leading to less liberalization.

\section{Conclusions}

Recognizing that the political economy of FDI demand has so far received less attention as opposed to the study of FDI supply, this paper has proposed a challenging analysis seeking to unify these two dimensions of FDI politics. Using a common agency model of politics, we have proposed a modelling of a reform aimed at relaxing FDI policies that account for the impact of direct lobbying of a domestic lobby and a foreign MNC lobby which compete for influencing the FDI policy process affecting firms' market access. The domestic lobby supports a low level of liberalization as it seeks protection from competing foreign investors. On the other hand, the MNC lobby supports more liberalization at it seeks market access. Contrary to conventional political economy models, we have assumed that the population exhibits heterogeneous political beliefs over the effects of FDI liberalization policies.

Our general model has suggested interesting results under specific conditions. First, proposition 1 has shown that when interest groups have the same lobbying efficiency, the lobbies' influence is not necessarily distortive. Indeed, taking into account the heterogeneity of citizen's beliefs over the effects of FDI policies, the equilibrium level of policy change is equal to its socially optimal value for a specific distribution of informed over misinformed citizens. Although conventional results of common agency models of lobbying have demonstrated that interest groups' activities bias policy choices against unorganized stakeholders, our model shows that it is not always the case. This result lies with the structure of the political game where the two lobbies holding opposed interests may provide the same lobbying efforts. Second, we have shown that a change in the distribution of informed over misinformed citizens creates political distortions as the equilibrium outcome deviates from its socially optimal level. For instance, when the number of misinformed increases, we paradoxically observe a strengthening of liberalization of FDI policies. This counter-intuitive result has to do with interdependence effects that occur between the two groups who share a common interest, namely the domestic lobby and the misinformed. Second, our model has also accounted for the effect of exogenous provision of information on the beneficial effects of the liberalization of FDI policies. In extending proposition 1, proposition 2 has shown that the liberalization process is weakened when such provision occurs. This 
paradoxical outcome also results from interdependence effects between lobby groups and the evolution of citizens' beliefs. This theoretical result has important policy implications especially for education policies aiming at creating a support for FDI and international economic flows in general. Indeed, findings of the literature showing that educated individuals are persuaded by the economic benefits of FDI and support them, may not be transferred into more FDI liberalization depending on the structure of the political game of well-organized interests.

For further research, our model has, however, the following limitations and could be extended in many directions. First, we have considered a general index of FDI policies that affect foreign investors' market access. Further research would consider specific policies and integrate them into the industry's profit functions. In addition, developing an economic model that accounts for material sources of utility such as wages would enrich the realism of the model and bring interesting insights given the labor market effects of FDI. Then, testing our result would bring interesting insights into the empirical literature of the political economy of FDI. Finally, the high level of generality of our model allows us to apply it to other important political economy issues such as those related to labor market regulations.

\section{Acknowledgements}

We thank participants of Research Seminar at the Department of Economics and Finance, United Arab Emirates University, February 2016. We are also thankful for the UAEU support, Grants number G00001588. Finally we thank Mr. Shahabuddin Abdulrouf, Mr. Enayatulah Abdal Ghafoor and Mr. Hamid Tajjudin for their excellent research assistance.

\section{References}

[1] UNCTAD (2013) World Investment Report 2013: Trends and Determinants. United Nations.

[2] Dunning, J. (1981) International Production and the Multinational Enterprise. Allen \& Unwin, London.

[3] Alfaro, L., Areendam, C., Sebnem, K. and Selin, S. (2004) FDI and Economic Growth: The Role of Local Financial Markets. Journal of International Economics, 64, 89-112. http://dx.doi.org/10.1016/S0022-1996(03)00081-3

[4] Siepza, V. (2004) Trade, FDI and Employment: Some Empirical Evidence. In: Lee, E. and Vivarelly, M., Eds., Understanding Globalization, Employment and Poverty Reduction, Palgrave Macmillan, New York, 143-162.

[5] Vacaflores, D.E. (2011) Was Latin America Correct in Relying in Foreign Direct Investment to Improve Employment Rates? Applied Econometrics and International Development, 11, 101-122.

[6] Kobrin, S.J. (2005) The Determinants of Liberalization of FDI Policy in Developing Countries: A Cross-Sectional Analysis, 1992-2001. Transnational Corporations, 14, 67-104.

[7] Pandya, S. (2007) Trading Spaces: Political Economy of Foreign Direct Investment Regulation, 1963-2000. PhD Dissertation, Harvard University, Cambridge, Mass. 
[8] Corden, W.R. (1974) Trade Policy and Economic Welfare. Claredon Press, Oxford.

[9] Bhagwati, J.N. (1985) Investing Abroad. Esmee Fairbain Lecture, University of Lancaster, Lancaster.

[10] Dinopoulos, E. and Wong, K. (1991) Quid pro quo Foreign Investment and Government Intervention. In: Koekkoek, K. and Mennes, C., Eds., International Trade and Global Development, Routledge, London, 162-190.

[11] Hillman, A. and Ursprung, H. (1999) Foreign Direct Investment and Endogenous Protection with quid pro quo. Economics and Politics, 11, 1-12. http://dx.doi.org/10.1111/1468-0343.00050

[12] Zhao, L. (1996) The Complementarity between Endogenous Protection and Direct Foreign Investment. Economics and Politics, 8, 61-72. http://dx.doi.org/10.1111/j.1468-0343.1996.tb00121.x

[13] Cooray, A., Tamazian, A. and Chaitanya Vadlamannati, K. (2014) What Drives FDI Policy Liberalization? An Empirical Investigation. Regional Science and Urban Economics, 49, 179-189. http://dx.doi.org/10.1016/j.regsciurbeco.2014.06.008

[14] UNCTAD (1996) World Investment Report 1996: Trends and Determinants. United Nations.

[15] Bhagwati, J.N., Dinopoulos, E. and Wong, K.Y. (1992) Quid pro quo Foreign Investment. Proceedings of the Hundred and Fourth Annual Meeting of the American Economic Association, 186-190.

[16] Hillman, A. and Ursprung, H. (1993) Multinational Firms, Political Competition, and International Trade Policy. International Economic Review, 34, 347-363.

http://dx.doi.org/10.2307/2526917

[17] Ellingsen, T. and Warneryd, K. (1999) Foreign Direct Investment and the Political Economy of Protection. International Economic Review, 40, 357-379. http://dx.doi.org/10.1111/1468-2354.00019

[18] Sheve, K.F. (200) Economic Insecurity and the Globalization of Production. American Journal of Political Science, 48, 662-674. http://dx.doi.org/10.1111/j.0092-5853.2004.00094.x

[19] Caplan, B. (2002) Systematically Biased Beliefs about Economics: Robust Evidence of Content-Dependent Judgmental Anomalies from the Survey of Americans and Economists on the Economy. Economic Journal, 112, 1-26. http://dx.doi.org/10.1111/1468-0297.00041

[20] Hiscox, M.J. (2006) Through a Glass and Darkly: Attitudes towards International Trade and the Curious Effects of Issue Framing. International Organization, 60, 755-780. http://dx.doi.org/10.1017/S0020818306060255

[21] Pandya, S. (2010) Labor Market and the Demand for Foreign Direct Investment. International Organization, 64, 389-409. http://dx.doi.org/10.1017/S0020818310000160

[22] Grossman, G. and Helpman, E. (1994b) Protection for Sale. American Economic Review, 84, 833-850.

[23] Converse, P.E. (1964) The Nature of Belief Systems in Mass Publics. Critical Review, 18, 174. http://dx.doi.org/10.1080/08913810608443650

[24] Page, B. and Shapiro, R. (1992) The Rational Public: Fifty Years of Trends in Americans' Policy Preferences. University of Chicago Press, Chicago. http://dx.doi.org/10.7208/chicago/9780226644806.001.0001

[25] Deli, C., Michael, X. and Keeter, S. (1996) What Americans Know about Politics and Why It Matters. Yale University Press, New Haven. 
[26] Rodrik, D. (2014) When Ideas Trump Interests: Preferences, Worldviews and Policy Innovations. Journal of Economic Perspectives, 28, 189-208.

http://dx.doi.org/10.1257/jep.28.1.189

[27] Leeson, P.T., Ryan, M.E. and Williamson, C.R. (2012) Think Tanks. Journal of Comparative Economics, 40, 62-77. http://dx.doi.org/10.1016/j.jce.2011.07.004

[28] Tagkalakis, A. (2006) Labor Market Reforms in a Monetary Union. Oxford Economic Papers, 58, 655-680. http://dx.doi.org/10.1093/oep/gpl012

[29] Jaeck, L. and Kim, S. (2014) The Impact of EMU Enlargement on Structural Reforms: A Political Economy Approach. International Advances in Economic Research, 20, 73-86. http://dx.doi.org/10.1007/s11294-013-9449-5

[30] Radosevic, S., Varblane, U. and Mickiewicz, T. (2003) Foreign Direct Investment and Its Effect on Employment in Central Europe. Transnational Corporations, 12, 53-90.

[31] Dinga, M. and Munich, D. (2010) The Impact of Territorially Concentrated FDI on Local Labor Markets: Evidence from the Czech Republic. Labour Economics, 17, 354-367. http://dx.doi.org/10.1016/j.labeco.2009.06.003

[32] Saint-Paul, G. (2004) Why Are European Countries Diverging in Their Unemployment Experience. Journal of Economic Perspectives, 18, 49-68. http://dx.doi.org/10.1257/0895330042632672

[33] Jaeck, L. (2011) Information and Political Failures: To What Extent Does Rational Ignorance Explain Irrational Beliefs Formation? Constitutional Political Economy, 22, 287-301. http://dx.doi.org/10.1007/s10602-011-9108-x

[34] MacDonald, S.E. and Rabinowitz, G. (1993) Ideology and Candidate Evaluation. Public Choice, 76, 59-78. http://dx.doi.org/10.1007/BF01049343

[35] Mac Culloch, R.J., Di-Tella, R. and Oswald, A.J. (2001) Preferences over Inflation and Unemployment: Evidence from Surveys of Hapiness. American Economic Review, 91, 335341. http://dx.doi.org/10.1257/aer.91.1.335

[36] Olson, M. (1965) The Logic of Collective Action. Harvard University Press, Cambridge.

[37] Insitute for Democracy and Electoral Assistance (IDEA) (2011) Political Finance Database. http://www.idea.int/political-finance/

[38] Aidt, T.S. and Hwang, U. (2014) To Ban or Not to Ban: Foreign Lobbying and Cross-National Externalities. Canadian Journal of Economics, 47, 272-297. http://dx.doi.org/10.1111/caje.12074

[39] Gawande, K., Krishna, P. and Robbins, M. (2006) Foreign Lobbies and US Trade Policy. Review of Economics and Statistics, 88, 563-571. http://dx.doi.org/10.1162/rest.88.3.563

[40] Bernheim, D. and Whinston, M. (1986) Menu Auction, Resource Allocation and Economic Influence. Quarterly Journal of Economics, 51, 1-31. http://dx.doi.org/10.2307/1884639

[41] Aitken, B., Ann, H. and Lipsey, R.E. (1996) Wages and Foreign Ownership: A Comparative Study of Mexico, Venezuela, and the United States. Journal of International Economics, 40, 345-371. http://dx.doi.org/10.1016/0022-1996(95)01410-1

[42] Chari, A. and Nandini G. (2008) Incumbents and Protectionism: The Political Economy of Foreign Entry Liberalization. Journal of Financial Economics, 88, 633-656. http://dx.doi.org/10.1016/j.jfineco.2007.07.006 
Submit or recommend next manuscript to SCIRP and we will provide best service for you:

Accepting pre-submission inquiries through Email, Facebook, LinkedIn, Twitter, etc. A wide selection of journals (inclusive of 9 subjects, more than 200 journals)

Providing 24-hour high-quality service

User-friendly online submission system

Fair and swift peer-review system

Efficient typesetting and proofreading procedure

Display of the result of downloads and visits, as well as the number of cited articles

Maximum dissemination of your research work

Submit your manuscript at: http://papersubmission.scirp.org/

Or contact tel@scirp.org 